\title{
Обзор докладов Второй Международной конференции «Корпоративное управление и устойчивое развитие бизнеса: стратегические роли советов директоров». Блок «Корпоративная социальная ответственность»
}

\begin{abstract}
Алекс Сеттлз ${ }^{39}$
Десять лет назад нельзя было предположить, что популярность проблематики корпоративного управления достигнет в России сегодняшнего уровня. Академические исследователи и профессиональ-практики регулярно собираются за одним столом, чтобы обсудить результаты исследований, направления развития и потенщиальные пути решения существующих проблем. Конщепщия корпоративной социальной ответственности, похоже, будет иметь аналогичную историю развития. Вопрос построения эффективной системы взаимоотношений со стейкхолдерами становится все более популярным. В данном обзоре мы попытаемся осветить основные положения докладов, связанных с проблемой развития принципов корпоративной соџиальной ответственности в России и за рубежом.
\end{abstract}

Представленные на этой секции доклады показали, что российские компании чаще применяют в своей работе принципы корпоративной социальной ответственности, нефинансовые стейкхолдеры становятся неотъемлемой частью эффективной системы корпоративного управления. Джорджия Петкоски, Институт Всемирного Банка, в своем докладе «Корпоративная ответственность и ответственная конкурентоспособность» представил обзор проблем корпоративной социальной ответственности в глобальном контексте. Г-н Петкоски охарактеризовал проблемы, с которыми сталкиваются страны с развивающейся и переходной экономикой, включая проблемы, связанные с быстрым экономическим ростом и изменением глобального климата. Удивительно, но изменения климата будут оказывать очень серьезное влияние экономического и социального характера. Развивающиеся страны в первую очередь пострадают от таких изменений, как изменение уровня моря, увеличение температуры, эрозия лесных и сельскохозяйственных систем, а также увеличение непредсказуемости погодных изменений. В соответствии с мнением Всемирного Банка, принятие принципов корпоративной социальной ответственности - это согласие корпоративного сектора с необходимостью управления и улучшения экономического, экологического и социального воздействия компаний на всех возможных уровнях (корпоративном, региональном и глобальном). Принципы корпоративной социальной ответственности - это новая система улучшения конкурентоспособности компаний, которая включает необходимость установления тесных взаимоотношений между межотраслевыми корпоративными объединениями и представителями государства и гражданского общества.

Внедрение принципов корпоративной социальной ответственности позволит снизить издержки, увеличить выручку, уменьшить операционные риски, стимулировать инновационное развитие, облегчить доступ на товарные рынки и рынки капитала, повысить репутацию. Все это должно привести к усилению конкурентного положения корпорации на глобальном рынке. В ближайшем будущем компании столкнутся с проблемой корректировки известной стратегии использования дешевой рабочей силы в сторону увеличения производительности рабочей силы. В основе конкуренции на глобальных рынках лежит технология и знания. Конкуренция по ценовому фактору фактически заканчивает свое существование. Поддержание конкурентоспособности требует эффективной работы с

\footnotetext{
${ }^{39} \mathrm{Ph} . \mathrm{D} .$, профессор, кафедра общего и стратегического менеджмента ГУ-ВШЭ.
} 
персоналом. Компании фактически вступают в третий этап развития концепции корпоративной социальной ответственности. Интересы индивидуального инвестора уступают системе взаимоотношений со стейкхолдерами. Уже многие компании открыли для себя необходимость в согласованных коллективных действиях и понимают важность тенденции изменения рыночных принципов, которые определяются в том числе ответственностью перед стейкхолдерами. Леонид Полищук из центра IRIS (Университет Мэриленда) представил обзор корпоративной социальной ответственности в своем докладе «Почему корпоративная социальная ответственность? Нормативные основы, примеры из бизнеса и проблемы внедрения». Для общественной оценки феномена корпоративной социальной ответственности и стратегий КСО необходим нормативный анализ данного явления, агрегирующий интересы компаний, потребителей и иных стейкхолдеров. Деятельность компаний связана с издержками для общества, значительная часть которых не возмещается компаниями и носит характер «экстерналий». Государственное регулирование не учитывает эти издержки в полном объеме («закон - неполный контракт»), вследствие чего возникает необходимость в частном урегулировании не охваченных законодательством экстерналий. Профессор Полищук заявил, что корпоративная социальная ответственность лучше, чем государственное регулирование, справляется с решением перечисленных задач в силу преимуществ частного сектора в заполнении рыночных ниш, использовании рыночной информации и более высокой склонности к инновациям.

Алексей Костин, исполнительный директор некоммерческого партнерства «Корпоративная социальная ответственность - Русский Центр», предложил к обсуждению концепцию корпоративной социальной ответственности в своем докладе «Корпоративная социальная ответственность: зачем она бизнесу и в чем роль государства?». Корпоративная социальная ответственность в развитых странах мира и постепенно в России определяется как «концепция интеграции заботы о социальном и экологическом развитии в бизнесоперациях компаний во взаимодействии со своими акционерами и внешней средой». Иерархия инструментария КСО в КУ:

- Миссия и ценности, кодекс корпоративной этики.

- Стратегия компании. Цели устойчивого развития (экономические, экологические и социальные).

- Концепция управления НФР и взаимодействия со стейкхолдерами.

- Мероприятия по КСО и устойчивому развитию.

- Социальная (по устойчивому развитию) отчетность.

- Коммуникации (ПР, Интернет и интранет, межсекторное партнерство).

Алексей Костин отметил, что этой связи для обеспечения корпоративной устойчивости все стороны КУ должны уделять большее внимание внедрению принципов и инструментария КСО и управления НФР в практику КУ, включая введение в СД исполнительных, а лучше независимых директоров по данным направлениям, созданию комитетов СД по КСО (УНФР, корпоративной устойчивости), а также внедрению социальной (по устойчивому развитию) отчетности.

Елена Феоктистова, заместитель руководителя департамента социальной политики РСПП, в своем докладе «Взаимодействие со стейкхолдерами как элемент управления ответственностью» представила обзор существующих инициатив российских компаний в области корпоративной социальной ответственности. Ее предложение состоит в том, что корпоративная социальная ответственность:

1. Лежит в основе эффективных бизнес-стратегий, прежде всего связанных с деятельностью и задачами развития каждой конкретной компании.

2. Подразумевает соблюдение баланса интересов акционеров, работников и их семей, потребителей товаров и услуг, партнеров по бизнесу, местных сообществ и окружения, построение добросовестных отношений со всеми заинтересованными сторонами. 
3. Базируется на соблюдении законодательства и включает дополнительные добровольные инициативы, находящиеся в постоянном процессе развития в результате взаимодействия с заинтересованными сторонами внутри самой компании и за ее пределами.

РСПП продолжает вести работу по созданию эффективной системы взаимоотношений между российскими компаниями и стейкхолдерами и выделяет следующие инструменты:

- Участие в отраслевых/региональных тарифных соглашениях, коллективных договорах - регулирование социально-трудовых отношений на основе баланса интересов работодателей и работников.

- Организация деятельности профильных комитетов совета директоров с участием представителей акционеров для выработки заключений по ключевым решениям поддержание обратной связи с акционерами.

- Заключение и реализация соглашений о сотрудничестве с властными структурами регионов присутствия компании - отношения с властью.

- Установление партнерств с участием органов власти, бизнеса и НКО взаимодействие с местными сообществами для решения общественно значимых проблем на основе учета взаимных интересов.

- Организация и проведение диалогов с заинтересованными сторонами формирование конструктивных отношений с целевыми группами.

- Развитие эффективных PR-коммуникаций - построение информационной политики на принципах открытости.

- Внедрение в корпоративную практику регулярной нефинансовой отчетности повышение прозрачности деятельности, улучшение взаимопонимания и диалога с заинтересованными сторонами.

Принципы ответственного ведения бизнеса базируются на концепции взаимодействия с заинтересованными сторонами, что находит отражение в основных регламентирующих документах международного и национального уровней.

Денис Гаврилов, институт оценки программ и политики, Государственный университет - Высшая школа экономики, представил доклад на тему «Влияние программ корпоративной социальной ответственности на имидж компании». Автор предложил обсудить вопрос. должны ли компании следовать принципам корпоративной социальной ответственности с целью улучшения их имиджа, повышения эффективности системы взаимодействия с потребителями и обеспечения долгосрочных преимуществ на рынке. Вывод автора состоит в том, что российские компании в первую очередь должны изучить опыт развитых стран и использовать наилучшие примеры из корпоративной практики. 